\title{
Determination of Nutritive Value and Mineral Elements of Some Species of Genus Memecylon Linn. from Central Western Ghats
}

\author{
Asha $\mathrm{B}^{1}$, Krishnappa $\mathrm{M}^{1^{*}}$ and Kenchappa $\mathbf{R}^{2}$ \\ 1Department of Applied Botany, Kuvempu University, Shankaraghatta-577 451, \\ Shimoga District, Karnataka, India
}

${ }^{2}$ Department of P.G. Studies and Research in Industrial Chemistry, Kuvempu University, Shankaraghatta-577 451, Karnataka, India

\begin{tabular}{|c|c|}
\hline Abstract & Article Information \\
\hline \multirow{3}{*}{$\begin{array}{l}\text { Five species of Memecylon were investigated for proximate analysis and elemental } \\
\text { composition. These species include } M \text {. umbellatum } M \text {. malabaricum, M. talbotianum, } M \text {. } \\
\text { wightii and } M \text {. lushingtonii. Among the proximates } M \text {. wightii showed highest } \\
\text { percentage of ash, crude fiber and carbohydrate. M. umbellatum showed high } \\
\text { percentage of moisture and crude fat. Crude protein was more in } M \text {. malabaricum. } \\
\text { Nutritive value was highest in } M \text {. lushingtonii among all the species. Among the } \\
\text { macronutrients } \mathrm{Na} \text { and } \mathrm{K}, \mathrm{Ca} \text { and } \mathrm{Mg} \mathrm{P} \text { and } \mathrm{N} \text { were highest in } M \text {. malabaricum, } M \text {. } \\
\text { talbotianum and } M \text {. umbellatum respectively. M. umbellatum recorded highest values } \\
\text { of } \mathrm{Cu} \text { and Mn where as } M \text {. lushingtonii and } M \text {. wightii recorded highest values of } \mathrm{Zn} \text { and } \\
\mathrm{Fe} \text {. Among the heavy metals } \mathrm{Pb} \text { and Cd } M \text {. umbellatum recorded highest values of } \mathrm{Pb} \\
\text { and } M \text {. talbotianum recorded highest values of } \mathrm{Cd} \text { but both the heavy metals are absent } \\
\text { in } M \text {. malabaricum. }\end{array}$} & $\begin{array}{l}\text { History: } \\
\text { ed : } 13-09- \\
\text { d : } 19-12- \\
\text { ted : } 21-12-\end{array}$ \\
\hline & $\begin{array}{l}\text { ls: } \\
\text { on }\end{array}$ \\
\hline & \\
\hline & \\
\hline
\end{tabular}

\section{INTRODUCTION}

The most important nutrients present in plants are carbohydrates, oil, proteins, minerals, ascorbic acid and the antioxidant phenols (Ekanayake and Nair, 1998). The trace elements together with other essential nutrients are necessary for growth, normal physiological functioning and maintaining of life. These trace elements must be supplied by food because the body cannot synthesis them. They required by the body in amounts less than 100 $\mathrm{mg}$ daily and deficiency of some of these trace elements can lead to diseases (Janab and Thompson, 2002).

Plants have great importance due to their nutritive value and a major source of medicines as they have been found throughout human history (Balick et al., 1996). Human body comprises chemical compounds such as water proteins, fatty acids, nucleic acids and carbohydrates these in turn consists of elements such as carbon, hydrogen, oxygen, nitrogen and phosphorus and may or may not contains minerals such as calcium, iron, magnesium and zinc (Katzmaezyk and Waist, 2004).

Each medicinal plant species has its own nutrient composition besides having pharmacologically important phytochemicals. These nutrients are essential for the physiological functions of human body and they play an important role in satisfying human needs for energy and life processes (Hoffman et al., 1998; Mathews et al., 1999; Dingman, 2002).
Memecylon Linn. belongs to the family Melastomaceae / Memecylaceae and there are about 150 species are reported from different regions of the world. The different floras, taxonomic literatures and other publications were referred and the identified species are recorded.

There are a few reports regarding the medicinal uses of a few species of Memecylon Linn. Nadakarni (1976) mentioned the medicinal use of $M$. amplexicaule, $M$. angustifolium and $M$. edule. Kirtikar and Basu (1991) reported the uses of leaves of $M$. umbellatum for the treatment of leucorrhoea and gonorrhea; they also mentioned the application of flowers and shoots of $M$. amplexicaule for the treatment of skin diseases. In addition the root of $M$. amplexicaule acts as ecobolic. The bark of $M$. angustifolium is used as a tonic and refrigerant. Maruthi et al. (2000) reported the application of leaves of $M$. umbellatum for the treatment of herpes. It is also reported that $M$. edule is used for contusion and the roots of $M$. harmandi in the treatment of diabetes (Ayyanara and Ignacimuthu, 2005). The crushed leaves extracts of $M$ malabaricum is used in the treatment of skin problems. In addition to medicinal uses the wood of $M$. umbellatum is an excellent source of firewood and charcoal. The pulp of the fruit is edible, the leaves and flowers contain dyes and these dyes are employed in the dyeing industry to dye the mats and cotton fabrics (Subhash, 1988). The fruit of $M$. edule has been being used by the tribal community of 
Asha et al.,

Tamil Nadu. Hullihatti et al. (2004) studied the antimicrobial activity of leaves of $M$. malabaricum. Amalraj and Ignacimuthu (1998) evaluated the hypoglycemic effect of $M$. umbellatum in normal \& alloxan diabetic mice.

\section{MATERIALS AND METHODS \\ Study Area}

Karnataka state is situated between $11^{\circ} 40^{\prime}$ and $18^{\circ} 27$ north latitude and $74^{\circ} 5^{\prime}$ and $78^{\circ} 33^{\prime}$ east longitude in the center of western peninsular India. The area of Karnataka comprises of about 1, 92,204 square kilometers. The state is broadly divided into two climatic regions namely southern and northern Karnataka. The southern Karnataka is rich in forests and receives maximum rain during the south west monsoon. The northern Karnataka has comparatively dry region.

\section{Sample Collection}

The leaves of $M$. umbellatum Burm. were collected from two different regions of Karnataka. The species was identified with the help of some taxonomic literature [Flora of British India (Hooker, 1894); flora of presidency of Madras (Gamble, 1928), flora of Davanagere District (Manjunathet al., 2002), (Yoganarasimhan et al., 1982), Compendium of Indian Medicinal plants (Rastogi and Mehrohra, 1991), flora of Presidency of Bombay (Cooke, 1903), The forest trees of Travancore (Bourdillon, 1908), flora of south Indian hill stations (Fyson, 1932; Flora of Coorg (Kodagu); (Keshava Murthy and Yoganarasimhan, 1990); Flora of Hassan District; Saldanha, 1976)]. The voucher specimens are deposited as herbarium in the department of Applied Botany, Kuvempu University.

\section{Sample Preparation}

The collected leaves were washed thoroughly 2-3 times with running tap water and once with sterile water, shade dried, powdered and stored in airtight bottles for further investigation.

\section{Nutritive Value and Elemental Composition}

The components of nutritive value and elemental composition were estimated by following the standard procedures (Indrayana et al., 2005; Deepak Dhyani, 2007 and Gali et al., 1999) at the department of Applied Botany, Kuvempu University and Central Coffee Research
Sci. Technol. Arts Res. J., Oct-Dec 2015, 4(4): 58-64

Institute, Balehonnur by using Atomic Absorption Spectroscopy (AAS) and Flame Photometer.

\section{Statistical Analysis}

Each experiment was repeated for three times. The results were represented with their means, standard deviation and standard error. The correlation matrix has been calculated.

\section{RESULTS}

\section{Components of Nutritive Value}

The average values of proximate of five species of Memecylon Linn represented in table 1. The percentage of ash was highest in $M$. wightii $(5.32 \%)$ it was followed by $M$. lushingtonii (5.16\%), M. malabaricum (4.82\%), $M$. talbotianum (3.99\%) and M. umbellatum (3.16\%).

The M. umbellatum contain highest of $53.99 \%$ of moisture and $M$. wightii contain lowest of $46.83 \%$ of moisture $M$. malabaricum, $M$. talbotianum and $M$. lushingtonii recorded 48.99, 48.91 and $48.16 \%$ moisture respectively.

The crude fat percentage was highest in $M$. umbellatum $(6.08 \%)$ and it was followed by M. Iushingtonii $(5.99 \%), \quad M$. malabaricum $(5.61 \%), \quad M$. talbotianum (5.53\%) and $M$. wightii (4.95\%).

The crude fiber percentage was highest in $M$. wightii $(6.08 \%)$ and lowest in $M$. umbellatum (3.62\%) and $M$. lushingtonii, $M$. malabaricum, and $M$. talbotianum recorded $4.86,4.32$ and $4.16 \%$ of crude fiber respectively.

The percentage of crude protein was highest in $M$. malabaricum $(1.87 \%)$, and it was followed by $M$. wightii, $M$. talbotianum, $M$. lushingtonii and $M$. umbellatum recorded 1.86, $1.8,1.78$ and $1.68 \%$ of crude protein respectively.

M. wightii recorded highest of $40.99 \%$ of carbohydrate and $M$. umbellatum recorded lowest of $35.05 \%$ of carbohydrate $M$. talbotianum, M. lushingtonii and $M$. malabaricum recorded $39.76,38.87$ and $38.65 \%$ respectively.

Table 1: Average values of proximates [moisture, ash, crude fat, crude fiber, crude protein and carbohydrate (in \%) and nutritive values (in cal/100gm)] of five species of Memecylon Linn

\begin{tabular}{lccccccc}
\hline \multicolumn{1}{c}{ Samples } & Ash & Moisture & Crude fat & Crude fiber & $\begin{array}{c}\text { Crude } \\
\text { Protein }\end{array}$ & Carbohydrate & $\begin{array}{c}\text { Nutritive } \\
\text { Value }\end{array}$ \\
\hline M. umbellatum & $3.166 \pm 0.709$ & $54.000 \pm 2.268$ & $6.083 \pm 0.222$ & $3.625 \pm 0.231$ & $1.683 \pm 0.100$ & $35.054 \pm 1.586$ & $201.750 \pm 6.195$ \\
M. malabaricum & $4.833 \pm 0.843$ & $49.000 \pm 2.670$ & $5.625 \pm 0.386$ & $4.333 \pm 0.518$ & $1.872 \pm 0.137$ & $38.665 \pm 2.015$ & $212.792 \pm 8.578$ \\
M. talbotianum & $4.000 \pm 0.716$ & $48.917 \pm 1.584$ & $5.542 \pm 0.566$ & $4.167 \pm 0.544$ & $1.803 \pm 0.109$ & $39.692 \pm 1.209$ & $216.050 \pm 8.229$ \\
M. wightii & $5.167 \pm 0.527$ & $46.833 \pm 2.038$ & $4.958 \pm 0.804$ & $4.917 \pm 0.667$ & $1.870 \pm 0.116$ & $40.989 \pm 1.277$ & $216.125 \pm 12.35$ \\
M. lushingtonii & $5.167 \pm 0.500$ & $48.167 \pm 1.167$ & $6.000 \pm 0.333$ & $4.833 \pm 0.500$ & $1.787 \pm 0.163$ & $38.877 \pm 1.540$ & $216.667 \pm 7.500$ \\
\hline \multicolumn{7}{c}{ \pm Shows mean and standard error }
\end{tabular}

\section{Nutritive Value}

Among the five species three species of Memecylon namely $M$, lushingtonii (216.66), $M$. wightii (216.12) $M$. talbotianum (216.03) recorded more or less equal values of nutritive value but $M$. umbellatum recorded lowest of 201.74 and $M$. malabaricum recorded $213.03 \mathrm{cal} / 100 \mathrm{gm}$ of nutritive value.

\section{Elemental Composition}

Table 2 shows Average values of elemental composition of five species of Memecylon Linn.

\section{Macronutrients}

Among the five macronutrients analyzed all the five species recorded highest percentage of $\mathrm{N}, \mathrm{Ca}$ and $\mathrm{K}$ and these were followed by $\mathrm{Na}, \mathrm{Mg}$ and $\mathrm{P}$ in $\mathrm{M}$. umbellatum, M. malabaricum, M. talbotianum and M. lushingtonii but in M. wightii $\mathrm{N}, \mathrm{Ca}$ and $\mathrm{K}$ were followed by $\mathrm{Mg}, \mathrm{P}$ and $\mathrm{Na}$. 
Table 2: Average values of elemental composition [macro (in \%), micro (in ppm) and heavy metals (in ppm) of five species of Memecylon

\begin{tabular}{|c|c|c|c|c|c|c|c|c|c|c|c|c|}
\hline \multirow[b]{2}{*}{ Samples } & \multicolumn{6}{|c|}{ Macro elements } & \multicolumn{4}{|c|}{ Micro elements } & \multicolumn{2}{|c|}{ Heavy metals } \\
\hline & $\mathrm{Na}$ & $\mathbf{K}$ & $\mathbf{P}$ & $\mathrm{Ca}$ & Mg & $\mathbf{N}$ & $\mathbf{Z n}$ & $\mathrm{Cu}$ & Mn & $\mathrm{Fe}$ & $\mathbf{P b}$ & Cd \\
\hline $\begin{array}{c}\text { M. } \\
\text { umbellatum }\end{array}$ & $\begin{array}{l}0.36 \pm \\
0.170\end{array}$ & $\begin{array}{c}0.655 \pm \\
0.196\end{array}$ & $\begin{array}{c}0.133 \pm \\
0.020\end{array}$ & $\begin{array}{c}0.646 \pm \\
0.249\end{array}$ & $\begin{array}{c}0.158 \pm \\
0.058\end{array}$ & $\begin{array}{c}8.648 \pm \\
0.274\end{array}$ & $\begin{array}{c}17.519 \pm \\
6.311\end{array}$ & $\begin{array}{c}74.358 \pm \\
58.929\end{array}$ & $\begin{array}{c}233.347 \pm \\
123.628\end{array}$ & $\begin{array}{c}284.289 \pm \\
122.138\end{array}$ & $\begin{array}{l}30.45 \pm \\
17.762\end{array}$ & $\begin{array}{l}0.48 \pm \\
0.279\end{array}$ \\
\hline $\begin{array}{c}M . \\
\text { malabaricum }\end{array}$ & $\begin{array}{l}0.66 \pm \\
0.125\end{array}$ & $\begin{array}{c}0.747 \pm \\
0.230\end{array}$ & $\begin{array}{c}0.071 \pm \\
0.022\end{array}$ & $\begin{array}{l}1.779 \pm \\
0.614\end{array}$ & $\begin{array}{c}0.224 \pm \\
0.075\end{array}$ & $\begin{array}{c}3.758 \pm \\
1.528\end{array}$ & $\begin{array}{c}18.926 \pm \\
4.454\end{array}$ & $\begin{array}{c}28.717 \pm \\
18.366\end{array}$ & $\begin{array}{c}47.379 \pm \\
17.544\end{array}$ & $\begin{array}{c}304.523 \pm \\
87.221\end{array}$ & 0 & 0 \\
\hline $\begin{array}{c}M . \\
\text { talbotianum }\end{array}$ & $\begin{array}{l}0.37 \pm \\
0.159\end{array}$ & $\begin{array}{c}0.603 \pm \\
0.203\end{array}$ & $\begin{array}{c}0.086 \pm \\
0.032\end{array}$ & $\begin{array}{c}1.722 \pm \\
0.869\end{array}$ & $\begin{array}{c}0.227 \pm \\
0.106\end{array}$ & $\begin{array}{c}7.582 \pm \\
0.469\end{array}$ & $\begin{array}{c}17.262 \pm \\
6.630\end{array}$ & $\begin{array}{c}10.681 \pm \\
5.017\end{array}$ & $\begin{array}{c}142.030 \pm \\
79.420\end{array}$ & $\begin{array}{c}312.233 \pm \\
130.141\end{array}$ & $\begin{array}{c}12.961 \pm \\
12.961\end{array}$ & $\begin{array}{c}0.328 \pm \\
0.328\end{array}$ \\
\hline $\begin{array}{c}M . \\
\text { wightii }\end{array}$ & $\begin{array}{l}0.11 \pm \\
0.014\end{array}$ & $\begin{array}{c}0.801 \pm \\
0.080\end{array}$ & $\begin{array}{c}0.148 \pm \\
0.020\end{array}$ & $\begin{array}{c}1.399 \pm \\
0.155\end{array}$ & $\begin{array}{c}0.299 \pm \\
0.062\end{array}$ & $\begin{array}{c}8.519 \pm \\
0.308\end{array}$ & $\begin{array}{c}25.579 \pm \\
6.279\end{array}$ & $\begin{array}{c}75.454 \pm \\
56.141\end{array}$ & $\begin{array}{c}55.801 \pm \\
4.694\end{array}$ & $\begin{array}{c}804.283 \pm \\
159.168\end{array}$ & $\begin{array}{c}51.163 \pm \\
2.868\end{array}$ & $\begin{array}{c}1.278 \pm \\
0.166\end{array}$ \\
\hline $\begin{array}{c}\text { M. } \\
\text { Iushingtonii }\end{array}$ & $\begin{array}{l}0.11 \pm \\
0.084\end{array}$ & $\begin{array}{c}0.214 \pm \\
0.181\end{array}$ & $\begin{array}{c}0.043 \pm \\
0.030\end{array}$ & $\begin{array}{c}0.251 \pm \\
0.206\end{array}$ & $\begin{array}{c}0.072 \pm \\
0.072\end{array}$ & $\begin{array}{c}3.872 \pm \\
2.243\end{array}$ & $\begin{array}{c}9.010 \pm \\
7.356\end{array}$ & $\begin{array}{c}14.998 \pm \\
13.251\end{array}$ & $\begin{array}{c}45.4033 \pm \\
38.8780\end{array}$ & $\begin{array}{c}191.945 \pm \\
149.226\end{array}$ & $\begin{array}{c}11.044 \pm \\
11.044\end{array}$ & $\begin{array}{c}0.283 \pm \\
0.283\end{array}$ \\
\hline
\end{tabular}

The highest percentage of $\mathrm{N}$ was recorded in $M$. malabaricum $(0.642 \%)$ and it was followed by $M$. umbellatum $(0.505 \%), M$. talbotianum $(0.485 \%), M$, lushingtonii $(0.306 \%)$ and $M$. wightii $(0.114 \%)$.

The percentage of $\mathrm{P}$ was highest in $M$. umbellatum $(0.176 \%)$ and lowest in $M$. malabaricum $(0.083 \%)$ and $M$. wightii, M. talbotianum and $M$, lushingtonii recorded 0.147 , 0.115 and $0.098 \%$ of $P$ respectively.

The highest percentage of $\mathrm{Ca}$ was highest in $M$. talbotianum $(2.133 \%)$ and it was followed by $M$. malabaricum $(1.828 \%), M$. wightii $(1.32 \%), \quad M$. umbellatum (1.164\%) and M. lushingtonii (0.666\%).

M. talbotianum recorded highest of $0.342 \%$ of $\mathrm{Mg}$ and $M$. lushingtonii recorded lowest of $0.187 \%$ of $\mathrm{Mg}$ and $M$. malabaricum, $M$. wightii and $M$. umbellatum recorded $0.328,0.298$ and $0.248 \%$ of $\mathrm{Mg}$ respectively.

$\mathrm{N}$ was the most dominant among the five macronutrient analyzed. The highest value of $\mathrm{N} 25.94 \%$ was recorded in M. umbellatum and it was followed by M. wightii (25.55\%), M. lushingtonii (23.23\%), M. talbotianum (23.17\%) and M. malabaricum (11.27\%).

\section{Micronutrients}

$M$, lushingtonii recorded highest value of $36.97 \mathrm{ppm}$ of $\mathrm{Zn}$ and M. malabaricum recorded lowest of $24.49 \mathrm{ppm}$ of $\mathrm{Zn}$. M. talbotianum, $M$. umbellatum and $M$. wightii recorded $33.43 \mathrm{ppm}, 30.17$ and $25.57 \mathrm{ppm}$ of $\mathrm{Zn}$ respectively.

$\mathrm{Cu}$ was highest in $M$. umbellatum (78.93ppm) and lowest in $M$. talbotianum $(15.15 \mathrm{ppm})$ and $M$. wightii, $M$. lushingtonii and $M$. malabaricum recorded moderate values of $74.03 \mathrm{ppm}, 35.91 \mathrm{ppm}$ and $26.72 \mathrm{ppm}$ of $\mathrm{Cu}$ respectively.

M. umbellatum recorded highest of 460.95ppm of $\mathrm{Mn}$ which is followed by $M$. talbotianum, $M$. lushingtonii, $M$. malabaricum and $M$. wightii and the values recorded were $263.81,210.42,58.97$ and 55.79 ppm respectively.

Fe was the dominant among the four micronutrients analyzed. $M$. wightii contain highest of $878.44 \mathrm{ppm}$ and M. malabaricum recorded lowest of $352.06 \mathrm{ppm}$ of $\mathrm{Fe}$ and M. lushingtonii, $M$. talbotianum and $M$. umbellatum recorded $658.80, \quad 560.46$ and $449.23 \mathrm{ppm}$ of $\mathrm{Fe}$ respectively.

\section{Heavy metals}

Among the two heavy metals analyzed $\mathrm{Pb}$ was dominant in all the five species. $M$. umbellatum recorded highest of $60.9 \mathrm{ppm}$ and $M$, lushingtonii recorded lowest of $44.17 \mathrm{ppm}$ of $\mathrm{Pb}$ and $M$. talbotianum and $M$. wightii recorded 51.84 and $51.07 \mathrm{ppm}$ of $\mathrm{Pb}$ respectively.

Cd was highest (1.13ppm) in $M$. talbotianum and lowest $(0.961 \mathrm{ppm})$ in $M$. umbellatum and $M$. wightii and $M$, lushingtonii recorded 1.27 and $1.13 \mathrm{ppm}$ of $\mathrm{Cd}$ respectively. M. malabaricum did not recorded both the heavy metals.

\section{Statistical Analysis Proximate Parameters}

Moisture and ash, fiber and moisture are negatively significantly correlated at 0.05 level, nutritive value and carbohydrate are positively significantly correlated at 0.05 level. Carbohydrate and moisture, nutritive value and moisture are negatively significantly correlated at 0.01 level where as fiber and ash are positively significantly correlated at 0.01 level (Table 3 ).

Table 3: Correlation matrix of proximate parameters

\begin{tabular}{|c|c|c|c|c|c|c|c|}
\hline & Ash & Moisture & Fat & Fiber & Protein & Carbohydrate & Nutritive value \\
\hline Ash & 1 & & & & & & \\
\hline Moisture & $-0.911^{*}$ & 1 & & & & & \\
\hline Fat & -0.542 & 0.701 & 1 & & & & \\
\hline Fiber & $0.967^{* *}$ & $-0.920^{*}$ & -0.546 & 1 & & & \\
\hline Protein & 0.795 & -0.854 & -0.755 & 0.682 & 1 & & \\
\hline Carbohydrate & 0.788 & $-0.966^{* *}$ & -0.814 & 0.818 & 0.839 & 1 & \\
\hline Nutritive value & 0.813 & $-0.959^{* *}$ & -0.546 & 0.841 & 0.762 & $0.930^{*}$ & 1 \\
\hline
\end{tabular}




\section{Elemental Composition}

Zinc and potassium are negatively significantly correlated at 0.05 level, cadmium and nitrogen, cadmium and lead are positively significantly correlated at 0.05 level. Magnesium and calcium, lead and nitrogen are positively significantly correlated at 0.01 level where as iron and sodium are negatively significantly correlated at 0.01 level (Table 4).

Table 4: Correlation matrix of elemental composition

\begin{tabular}{ccccccccccccc}
\hline & $\mathbf{N a}$ & $\mathbf{K}$ & $\mathbf{P}$ & $\mathbf{C a}$ & $\mathbf{M g}$ & $\mathbf{N}$ & $\mathbf{Z n}$ & $\mathbf{C u}$ & $\mathbf{M n}$ & $\mathbf{F e}$ & $\mathbf{P b}$ & $\mathbf{C d}$ \\
\hline $\mathbf{N a}$ & 1 & & & & & & & & & & & \\
$\mathbf{K}$ & 0.156 & 1 & & & & & & & & & & \\
$\mathbf{P}$ & -0.304 & 0.356 & 1 & & & & & & & & & \\
$\mathbf{C a}$ & 0.494 & 0.385 & -0.221 & 1 & & & & & & & & \\
$\mathbf{M g}$ & 0.329 & 0.565 & -0.142 & $0.962^{* *}$ & 1 & & & & & & & \\
$\mathbf{N}$ & -0.649 & -0.269 & 0.752 & -0.420 & -0.403 & 1 & & & & & & \\
$\mathbf{Z n}$ & -0.098 & $-0.952^{*}$ & -0.100 & -0.386 & -0.589 & 0.447 & 1 & & & & & \\
$\mathbf{C u}$ & -0.465 & 0.464 & 0.853 & -0.508 & -0.336 & 0.559 & -0.313 & 1 & & & & \\
$\mathbf{M n}$ & 0.281 & -0.215 & 0.602 & -0.188 & -0.346 & 0.524 & 0.496 & 0.270 & 1 & & & \\
$\mathbf{F e}$ & $-0.9855^{* *}$ & -0.162 & 0.247 & -0.349 & -0.192 & 0.625 & 0.092 & 0.355 & -0.334 & 1 & & \\
$\mathbf{P b}$ & -0.516 & -0.273 & 0.766 & -0.317 & -0.336 & $0.985^{* *}$ & 0.483 & 0.494 & 0.635 & 0.502 & 1 & \\
$\mathbf{C d}$ & -0.693 & -0.454 & 0.479 & -0.243 & -0.252 & $0.920^{*}$ & 0.557 & 0.238 & 0.321 & 0.725 & $0.905^{*}$ & 1 \\
\hline
\end{tabular}

\section{DISCUSSION}

The leaves of five species of Memecylon were analyzed for their moisture, ash, crude fat, crude fiber, crude protein, carbohydrate, nutritive value and mineral contents. The five species $M$. umbellatum, $M$. malabaricum, $M$. talbotianum, $M$. wightii and $M$. lushingtonii were selected for the present study.

The leaves have recorded ash content ranging from $3.16 \%$ for $M$. umbellatum, to $5.17 \%$ for $M$. wightii. The high content of ash is useful in assessing the quality of grading the plant and it also gives an idea of the amount of minerals present in the sample (Michael and David, 2002). Moisture content ranging from $46.83 \%$ for $M$. wightii to $54 \%$ for $M$. umbellatum, crude fat content ranging from $4.95 \%$ for $M$. wightii to $6.08 \%$ for $M$. umbellatum, The fat are primarily used to produce hormone like substances that regulate a wide range of functions, including blood pressure, blood clotting, blood lipid levels, the immune response and the inflammation response to injury infection. It play an important role in the life and death of cardiac cells because they are essential fuels for mechanical and electrical activities of heart (Reiffel and Donold, 2006; Landmark and Alm, 2006; Herbant, 2006). The fat content can be used for storage and transport forms of metabolic fuel (Michael and David, 2002). Crude fiber content ranging for $3.62 \%$ for $M$. umbellatum to $4.91 \%$ for $M$. wightii which plays an important role in decreasing the risks of many disorders such as constipation, diabetes, cardiovascular disease (CVD), diverticulosis and obesity (Spiller, 2001). Food fiber helps in absorption of trace elements in the gut (Kelsay, 1981) and reduces absorption of cholesterol (Le Veille and Sanberlich, 1966). The fiber also increases the bowel movement and promotes abortion. (Michael and David, 2002). Crude protein content ranging from $1.68 \%$ for $M$. umbellatum to $1.87 \%$ for $M$. malabaricum and $M$. wightii. Proteins contain amino acids which are utilized by the cells of the body to synthesize all the numerous proteins required for the function of the cell and also to furnish energy (Robinson, 1978). The low content of the protein can contribute to the formation of hormones which controls a variety of body functions such as growth repair and maintance of body protein (Mau et al, 1999). All the samples were rich in carbohydrate which is ranging from $35.05 \%$ for $M$. umbellatum to $40.98 \%$ for $M$. wightii, Carbohydrate constitutes a major class of naturally occurring organic compounds that are essential for the maintenance of plant and animal life and also provide raw materials for many industries (Ebun-Oluwa and Alade, 2007). The high carbohydrate content is used as energy source and also it is necessary in the digestion and assimilation of other foods (Michael and David, 2002). And nutritive value was ranging from $201.75 \%$ for $M$. umbellatum to $216.66 \%$ for M. Iushingtonii.

Among the macro nutrients the $\mathrm{Na}$ and $\mathrm{K}$ were highest in $M$. malabaricum. $\mathrm{Na}$ and $\mathrm{K}$ take part in ionic balance of the human body and maintain tissue excitability, carrying of normal muscle contraction help in the formation of gastric juice in stomach (Brody Tom, 1998). K helps in releasing of chemicals which are acts as nerve impulses, regulating heart rhythms. Its deficiency causes nervous irritability, mental disorientation, low blood sugar, insomnia and coma (Underwood and Suttle, 1999).

$\mathrm{Ca}$ and $\mathrm{Mg}$ were highest in $\mathrm{M}$. talbotianum. Ca plays an important role in building and maintaining of strong bones and teeth and also constitutes a large part of human blood and extra cellular fluids and it is also necessary for normal functioning of cardiac muscle, blood coagulation, milk clotting and regulation of cell permeability (Heaney, 1994). Its deficiency causes rickets, back pain, osteoporosis, indigestion, irritability, premenstrual tension and cramping of the uterus (Hasling et al., 1991). Mg plays an important role in the formation of bones, muscles and prevents high disorders, high blood pressure and depression (Smith and Hammarstam, 1958) along with these it also plays important role in enzyme activity, deficiency interfere with transmission of nerve and muscle, impulse, causing irritability and nervousness and in the prevention of heart diseases (Scelig, 1989). 
Asha et al.,

$\mathrm{P}$ and $\mathrm{N}$ were highest in $\mathrm{M}$. umbellatum. $\mathrm{P}$ helps in maintaining of blood sugar level, normal heart contraction dependent on P (Linder and Manria, 1991). Also important for normal cell growth and repair, which are needed for bone growth, kidney functions and cell growth. It also plays an important role in maintaining body's acid-alkaline balance (Johns and Dequette, 1991). N plays an important role in digestion of food and growth (Cooper, 1984) but in excess it is harmful for living body.

The micronutrients $\mathrm{Zn}$ and $\mathrm{Fe}$ were highest in $M$. lushingtonii and $M$. wightii respectively. In enzyme metabolism $\mathrm{Fe}, \mathrm{Mn}$ and $\mathrm{Zn}$ are the three essential elements. Fe is important in maintaining the good health of human being (Vaughan and Judd, 2003).

Whereas $\mathrm{Cu}$ and $\mathrm{Mn}$ were recorded high in $M$. umbellatum. $\mathrm{Mn}$ is a component of several enzymes including manganese-specific glycosyl transferase and phosphoenol pyruvate carboxykinase and essential for normal bone structure. Mn deficiency can cause manifest as transient dermatics, hypocholesterolemia and increased ALP level. Cu is a universally important cofactor for hundreds of enzymes. It functions as a cofactor and numerous enzymes which are involved in development and maintance of the cardiovascular system. The deficiency of $\mathrm{Cu}$ can result in a decrease in the tinsel strength of arterial walls, leading to aneurysm formation and skeletal mal development (Tilson, 1982). $\mathrm{Mn}$ is an important modulator of cells function and plays a vital role in the control of diabetes (Kore, 1988).

The toxic elements such as $\mathrm{Pb}$ and $\mathrm{Cd}$ were recorded highest in $M$. umbellatum and $M$. talbotianum respectively. Trace elements are essential for normal growth of plants, their protection against viruses and completion of their life cycle (Bennet et al., 2000).

Nutritional deficiency may lead to diseases e.g.; Kwashiorkor, goiter. The increasing use of highly refined foods which have low percentage of minerals, vitamins etc contributes to the problems of health. Dietary supplements which increase the total dietary intake of one or more essential vitamin or mineral are very common. USA alone spent about $\$ 3$ billion per year on vitamins, elements and nutritional products. The possible adverse effects of long term ingestion of high dose mineral supplements are unknown (Ivey and Elmen, 1986). The traditional healers prescribe mixture of medicinal plants for curing diseases ranging from common cold malaria, arthritis, ulcers etc (Obiajunwa et al., 2002). To prevent imminent development of diseases or for treatment of vitamin or mineral deficiencies nonprescription drugs such as minerals or vitamins are used (Hay, 1984).

The differences in the concentrations of various elements may be due to the differences in botanical structures of the plants and also due to the mineral composition of the soil. Moreover the differences may be due to the ability of plants to accumulate the elements from the surrounding aerial or aquatic environment either for their physiological requirement or as a precautionary measure (Viksna and Selin, 2001). Some inorganic mineral elements (potassium, zinc, calcium, traces of chromium, etc.) play important roles in the maintenance of normal glucose tolerance and in the release of insulin from beta cells of islets of Langerhans (Choudhary and Bandyopadhyay, 1999). All the plant parts have nutritional
Sci. Technol. Arts Res. J., Oct-Dec 2015, 4(4): 58-64

qualities which when used in the right proportions could be of tremendous benefit to the body (Abolaji et al., 2007).

The result of the present study reveals that $M$. umbellatum recorded highest values of moisture, crude fat, $\mathrm{P}, \mathrm{N}, \mathrm{Cu}, \mathrm{Mn}$ and $\mathrm{Pb}$ but low in nutritive value. Whereas $M$. malabaricum recorded lowest values of crude protein, $\mathrm{P}, \mathrm{N}, \mathrm{Zn}$ and $\mathrm{Fe}$ and it is very interesting to note that both the heavy metals $\mathrm{Pb}$ and $\mathrm{Cd}$ were almost absent in the sample and $M$. lushingtonii recorded highest amount of nutritive value. So these plants can be used as fodder for animals. Many researchers studied different plants for their nutritive value and element composition. Ekpa, (1996) studied nutrient composition of three Nigerian medicinal plants and recommended that the leaves of Ipomea aserifolia with high percentage of protein and low level of toxicity could be serve as a good source of food for form animals. Javid et al., (2010) clarifies the use of four medicinal plants from Pakistan with very lesser level of $\mathrm{Pb}$ as food supplement. Indrayana et al. (2005) analyzed some medicinally valued plant from Uttarachal and reported that Artocarpus heterophyllus leaves are not rich in desired mineral elemental and nutritive value. So, these leaves are good for those who require high sodium and also good as fodder.

\section{CONCLUSIONS}

In the present study the five species of Memecylon were investigated for proximate analysis and elemental composition. M. umbellatum recorded highest values of moisture, crude fat, phosphorus, nitrogen, copper, manganese and lead, $M$, malabaricum recorded highest values of crude protein, sodium, potassium. In this species both the heavy metals lead and cadmium were absent. M. talbotianum recorded highest values of calcium, magnesium and cadmium, where as $M$, wightii recorded highest values of ash, crude fiber, carbohydrate and iron and $M$. lushingtonii recorded highest values of nutritive value and zinc. From the obtained result it can be concluded that all these species of Memecylon may be further explored for their phytochemical profile to identify the presence of active constituents for medicinal uses.

\section{Conflict of Interest}

Conflict of interest none declared.

\section{Acknowledgements}

Authors thank the Chairman, Department of Applied Botany, Kuvempu University for providing laboratory facilities.

\section{REFERENCES}

Amalraj, T., Ignacimuthu, S. (1998). Evaluation of the hypoglycaemic effect of Memecylon umbellatum in normal and alloxan diabetic mice. Journal of Ethnopharmacology 62(3): 247-250.

Ayyanar, M., Ignacimuthu, S. (2005). Traditional knowledge of Kanitribals in Kouthalai of Tirunelveli hills, Tamil Nadu, India, Journal of Ethnopharmacology 102: 246-255.

Balick M, J., Paul and cox A. (1996). plant that heal; people and culture; the science of ethnobotany. Scientific American Library 73: 25-61.

Bennett, J.P., Chiriboga, E., Coleman, J. and Waller, D.M. (2000). Heavy metals in wild rice from Northern Wisconsin. Science of the Total Environment 246: 261269 
Asha et al.,

Bourdillon, T.F. (1908). The forest trees of Travancore, $1{ }^{\text {st }}$ Edn, reprinted-(1937), 172-174.

Brody Tom, (1998). Nutritional Biochemistry. San Diego Academic press 11-20.

Choudhary, K.A., Bandyopadhyay, N.G. (1999). Preliminary studies on the inorganic constituents of some indigenous hyperglycaemic herbs on oral glucose tolerance test. Journal of Ethnopharmacology 64: 179-184.

Cooke Theodore, C.I.E. (1903). Flora of the Presidency of Bombay, published under the authority of the secretary of state for India in Council London. Taylor and Francis, Red Lion Court, Fleet Street 1: 502-504.

Cooper, J. (1984). Structure and Biological activity of nitrogen and oxygen; coordinated nicotinic acid complexes of chromium. Inorganica chemica ACTA 91: 1-9.

Deepak Dhyani R.K., MaikhurRao K.S., Lathikumar, Purohit V.K., ManjuSundriyal and Saxena K.G. (2007). Basic nutritional attributes of Hippophaerhamanoides (Sea Buckthron) populations from Uttarakhand, Himalaya, India. Current Science 92(8): 1148-1152.

Dingman, S. L. (2002). Water in Soils; infiltrateion and redistribution. Physical Hydrology, second edition, upper saddle river. New Jersey Prentice -Hall, Inc 646.

Ebun-Oluwa, P.O., Alade, A.S. (2007). Nutritional potential of Berlandier Nettle spurge (Jatrophacathatica) seed. Pakistan Journal of Nutrition 6: 345-348.

Ekanayake, E.R., and Nair, B.M. (1998). Proximate composition mineral and amino acid content of mature Canavalieagladiala seeds. Food chemistry 66: 115-119.

Ekpa, O. D. (1996), Nutrient composition of three Nigerian medicinal plants. Food chemistry 57(2): 229-232.

Fyson, P.F. (1932). Flora of the South Indian Hill Stations, Ootacamund, Coonoor, Kotagiri, Kodaikanal, Yercand and the Country round, Madras. printed by the superintendent, Government Press 1: 231-233.

Gali, S.K., Poleshi, C.M., Sarangamath, P.A., Dasog, G.S., and Anegundi, K.M. (1999). Laboratory Manual for SAC 302, Soil Fertility (2+1). Department of Soil Science and Agricultural Chemistry, College of Agriculture Dharwad 580005.

Gamble, J.S. (1928). Flora of Presidency of Madras, Published under the authority of the secretary of state for India in council, London. Adlard and son, Limited 21, Hart Street, W.O, 1, 500 .

Hasling C., Sondergard K., Charles P., Moselkiloe. (1991). Calcium metabolism in postmenopausal osteoporotic woman is determined by dietary calcium and coffee intake. American Institute of Nutria 23: 119-126.

Hay, R. W. (1984). Bio-Inorganic Chemistry. Ellis Horwood Ltd, Chichester.

Heaney R.D. (1994). Thinking straight about calcium. The New England Journal of Medicine 328 (7): 503-505.

Herbant, C. (2006). Omega-3 and health (in French). Revue Médicale de Bruxelles 27(4): S835-60.

Hoffman, P.C., Combs, D.K., Casler, M.D., (1998). Performance of lactating dairy cows fed alfalfa silage or perennial ryegrass silage. Journal of Dairy Science 81 : 162-168.

Hooker, J.D. (1894). Flora of British India, Published under the authority of the secretary of state for India in Council.
Sci. Technol. Arts Res. J., Oct-Dec 2015, 4(4): 58-64

Reeve and Co., Ltd. The Oast House Brook Ashford Kent 3: 553.

Hullatti, K.K., Rai, R.V. (2004). Antimicrobial activity of Memecylon malabaricum leaves. Fitoterapia 75: 409-411.

Indrayan, A.K., Sudeep Sharma, Deepak Durgapal, Neeraj Kumar and Manoj Kumar. (2005). Determination of nutritive value and analysis of mineral elements for some medicinally valued plants from Uttaranchal. Current Science 89(7): 1252-1255.

Ivey, M.G., Elmen. (1986). Nutritional Supplements, Mineral and Vitamin Production. In: Handbook of Nonprescription Drugs, $8^{\text {th }}$ ed, American Pharmaceutical Association. The National Professional Society of Pharmacists, 2215 Constitution Avenue, N, W, Washington, DC 20037, USA 215.

Janab, M., Thompson, L.V. (2002). Role of phytic acid in cancer and other diseases. In: N.R., Reddy and sathe S.K., food phytates, CRC Press, Boca Raton, FL. 225248.

Javid, H., Riaz, Ullah., Najeebur, R., Abdul L.K., Zia, M., Farman, U.K., Syed, T.H., Saeed, A. (2010). Endogenous transitional metal and proximate analysis of selected medicinal plants from Pakistan. Journal of Medicinal Plants Research 4(3): 267-270.

Johns, T., Duquette, M. (1991). Deficiency of phosphorus in man. The American Journal of Clinical Nutrition 53: 448456.

Katzmarzyk, J.L., Waist R.R. (2004) Circuference and not body mass index explains obesity related health risk. The American Journal of Clinical Nutrition 79(3): 379-384.

Kelsay, J.L. (1981). Effects of diet fiber level on bowel function and trace mineral balances of human subjects. Cereal Chemistry 58: 2-5.

Keshava Murthy, K.R., Yoganarasimhan, S.N. (1990). Flora of Coorg (Kodagu), Karnataka, India, with data on Medicinal plants and chemical constituents. Vimsat Publishers, 802, III Main, IV Block, Rajajinagar, Bangalore-560010 191-193.

Kirtikar, K.R. and Basu, B.D. (1991). Indian Medicinal Plants. Periodical expert book agency Delhi 2:1325-1328.

Kore, M. (1998). Manganese homeostasis in human and its role in disease states. In: essential and toxic trace elements in human and disease. Prasad, A.S., (Ed). Alan R., Liss Inc., New York, ISBN. 10-0471614491.

Landmark, K., Alm, C.S. (2006). Alpha-linolenic acid, Cardiovascular disease and sudden death (in Norwegian). Tidsskrift for Den norske legeforening 126(21): 2792-4.

LeVeille, G.A., and Sauberlich, H.E. (1966). Mechanism of the cholesterol-depressing effect of pectin in the cholesterol-fed rat. Journal of Nutrition 88: 209-214.

Linder, Manria C. (1991). Nutritional Biochemistry and metabolism with clinical applications. Appleton and Lange, Norwalk 2: 191-212.

Manjunath, B.K., Krishna, V., and Pullaiah, T. (2002). Flora of Davanagere District, Karnataka, India. Regency Publications, New Delhi 212.

Maruthi, K.R., Krishna, V., Manjunatha, B.K. and Nagaraja, Y.P. (2000). Traditional Medicinal Plants of Davanagere District, Karnataka with Reference to Cure of Skin Diseases. Environment and Ecology 18(2): 441-446. 


\section{Asha et al.,}

Mathews, C.E., Van Holde K.E., Ahern, K.G. (1999). Biochemistry, ( $3^{\text {rd }}$ edn). Benjamin Cummings.

Mau, J.L., Miklus, M.B.,and Beelman, R.B. (1999). Shelf life studies of foods and Beverages charalambous E.d., Chemistry Bioogyl Physics Nutural Aspects 57: 475-477.

Michael, K.L., and David, M.P. (2002). The useful plants of West Tropical Africa Nigerian. Journal of biochemistry and molecular biology 12: 53-60.

Nadakarni, A.K. (1976). Indian Materiamedica. Dahootapapeshuar Prakashana Ltd, Mumbai 1(1): 452.

Abolaji, O.A., Adebayo, A.H., Odesanmi, O.S. (2007). Nutritional Qualities of Three Medicinal Plant Parts (Xylopiaaethiopica, Blighiasapida and Parinaripolyandra) commonly used by Pregnant Women in the Western Part of Nigeria. Pakistan Journal of Nutrition 6 (6): 665-668.

Obiajunwa, E.I., Adeleke C., Adebajo Olanrewaju, R., and Omobuwajo. (2002). Essential and trace element contents of some Nigerian medicinal plants. Journal of Radio analytical and Nuclear Chemistry 252(3): 473-476.

Rastogi Ram, P., and Mehrotra, B.N. (1991), Compendium of Indian Medicinal Plants. Central Drug Research Institute, Lucknow 2: 1970-1979.

Reiffel, J.A., Mc Donald, A. (2006). Antiarrhythmic effects of Omega-3 fatty acids. American Journal of Cardiology 98 (4A): $50 \mathrm{i}-60 \mathrm{i}$

Robinson, H. (1978). Fundamentals of normal nutrition, $3^{\text {rd }}$ edition. Macmillan publishing Co. Inc ISBN 002-979590, 41-125 272-284.

Saldanha Cecil, J., Dan, H.N. (1976). Flora of Hassan District, Karnataka, India. Amerind Publishing Co Pvt. Ltd 286-289.
Sci. Technol. Arts Res. J., Oct-Dec 2015, 4(4): 58-64

Scelig, M. (1989). Cardiovascular consequences of Mg deficiency and loss; pathogenesis, prevalence and manifestations--magnesium and chloride loss in refractory potassium repletion. American Journal of Cardiology 63 (14): 4G-21G

Smith, W.D., Hammarsten J.F. (1958). Serum Mg in clinical disorders. South Molecular Journal 51: 1116 -1117.

Spiller, G.A. (2001). Dietary fiber in prevention and treatment of disease. In: G.A., Spiller, (Eds). CRC handbook of dietary fiber in human nutrition, CRC press LLC. Washington 363-431.

Subhash Chandra, D. (1988). Systemic Botany, Wiley Eastern Limited, 27, Bull Temple Road, Basavanagudi, Bangalore 560 004, pp. 357.

Tilson, M.D. (1982). Decreased hepatic copper level. A possible chemical marker for the pathogenesis of aortic aneurysms in man. Archives of Surgery 117(9): 1212 1213.

Underwood E.J., Suttle N.F. (1999). The mineral nutrition of Livestock. CABI publishing, New York 51-101.

Vaughan, J. G., an. P. A., Judd, (2003). The oxford Book of Health Foods: A comprehensive guide to natural remedies. $1^{\text {st }}$ Edn. Oxford Univ. Press, New York, ISBN: 019-280680-7.

Viksna, A. E., Selin-Lindgren, Standzenieks, P. (2001). X-Ray Spectrom. 30: 260 .

Yoganarasimhan, S.N., Subramanyan, K. and Razi, B.A., (1982). Flora of Chikmagalore District, Karnataka, India. International Book Distributors Deharadun 145-146. 